\title{
Usher Syndrome Type 1
}

National Cancer Institute

\section{Source}

National Cancer Institute. Usher Syndrome Type 1. NCI Thesaurus. Code C126327.

A syndrome characterized by cong enital, bilateral, severe sensorineural hearing loss, abnormalities in the vestibular system, and adolescent-onset retinitis pigmentosa. 